\title{
Construction and Application of a Competence Model of Accounting Vocational Education
}

\author{
https://doi.org/10.3991/ijet.v14i21.11346 \\ Jinglei Zhong ( $\square$ ) \\ Hunan International Economics University, Changsha, China \\ $875258825 @ q q . c o m$
}

\begin{abstract}
Accounting vocational education directly bears on the competence of accountants, and affects the development of the accounting industry. In light of the background of vocational education, this paper develops a competence model of accounting vocational education in China, applies the established model in an actual case, and puts forward measures to improve the competence of accounting vocational education. The research results show that: the evaluation index system of accounting vocational education should highlight importance, incentives and effectiveness; the management and leadership ability is the primary factor of the competence of accounting vocational education; an excellent accounting vocational educator must enjoy outstanding management and leadership ability, accounting ability and accounting skills; the competence of accounting vocational education should be improved mainly through incentive measures, from the perspective of adjusting the education purpose. The research findings lay the theoretical basis for self-evaluation, selfmanagement and career planning of accounting vocational educators and accountants.
\end{abstract}

Keywords-Accounting vocational education, accounting industry, competence model, management and leadership ability

\section{$1 \quad$ Introduction}

As an important part of vocational education, accounting vocational education plays an increasingly important role in the country's development strategy of vocational education [1]. It's a vocational education for accounting science, in order to achieve the professional orientation, special skills training and employment settlement for accounting practitioners in vocational schools [2-3]. According to the data released by the China Institute of Certified Public Accountants, as of 2018, the number of accounting registrars in China has exceeded 12 million, ranking first in the world. However, the ability of accounting practitioners directly affects the competence of accountants [4]. At present, there are many graduates in the accounting field in China, but most students are not competent enough. In a strict sense, the competency of most accounting practitioners in China are not up to standard [5]. 
The competency of accounting vocational education is also called competency characteristics and competency quality. The competency model is used to distinguish the individual characteristics of performance level in specific position and organizational environment. The competency model of accounting vocational education is the sum of the competencies of an accounting practitioner [6-7]. At present, the competence model of accounting vocational education is constructed in the methods such as derivation, citation revision, and induction, etc., but the general competency model has too many factors, not always in line with the actual accounting industry [8]. Some research scholars constructed the competency model system of accounting vocational education from the four aspects: accounting tasks, task environment, specific performance standards, and ability to accomplish performance standards [9]. In light of the construction and application of competence model, this paper explores the competency of accounting practitioners under the accounting vocational education. This shall help for self-evaluation, self-management and career planning of accounting vocational educators and accountants.

\section{Competency Model Design and Index Construction of Accounting Vocational Education}

\subsection{Competency model design of accounting vocational education}

There are many typical views on the competence of accounting vocational education, including potential personal traits, external behaviours, and the compromise between the two. In accounting vocational education, the focus of competency lies in obtaining accounting knowledge and skills through lecturing or schooling [10]. The competency of accounting vocational education is to establish a specific technical system through integration and analysis for knowledge, skills and professional values and then apply it to practical work [11]. Competency is the embodiment of professional ability; competency behaviour is characterized by the trait of professional ability, while the actual consequence of competency is the potential of professional ability. The two are displayed differently, but the work results and learning outcomes are complementary [12]. The functional analysis of the accounting vocational education competency is based on the accounting role in actual work, the ability to accomplish the task, and especially the ability to achieve competence through the vocational education [13].

Figure 1 shows the competency modelling method. The accounting performance standards are manifested as accounting ability, key functions, accounting units and accounting elements. The competency performance standards studied in this paper were divided into two levels: conformity and excellence. The competency model established with excellent performance standards has consistency and aggregation effects. The competency model of accounting vocational education was divided into excellent group and ordinary group according to performance standards. The number of samples was sufficient for hypothesis of statistical testing and identification of 
competence characteristics. Common methods of data collection include behavioural event interviews, expert methods, questionnaires, and expert system methods [14].

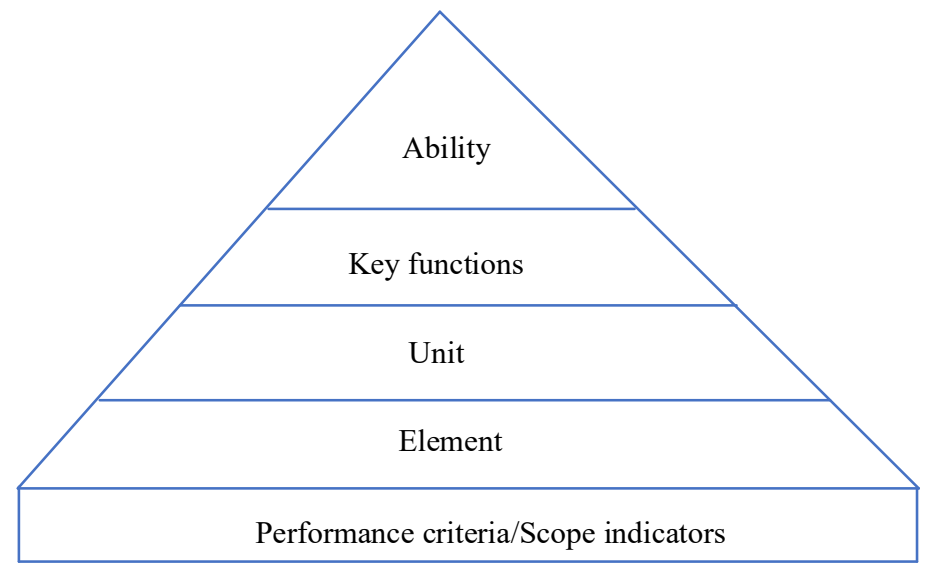

Fig. 1. Competency method

\subsection{Evaluation index system construction of accounting vocational education}

When the competence of accounting vocational education is applied to a specific work environment, it's expressed as the competence of the accountant, esp., their professional competence and skills. Factors affecting the vocational competence of accountants in a specific environment include the matching degree between personal interest and job position, and corporate culture system. The vocational competence evaluation index system of accountants should follow the principles of importance, incentive and effectiveness. A good accountant must learn to integrate his or her professional competence according to environmental changes, showing good personality characteristics, teamwork, professional skills, professional knowledge and professional values. Table 1 shows the definition of competency characteristics of accounting vocational education by the International Federation of Accountants. The characteristics are categorized into professional knowledge, professional skills and professional attitudes: the competency characteristics of professional knowledge include financial accounting knowledge, enterprise management knowledge and computer application knowledge; professional skills include analytical skills, collaboration and communication skills, and organizational management skills; professional attitudes include professional ethics and compliance with the law. Figure 2 shows the relationship between competency and personal characteristics and task performance. The evaluation of an accountant's competency is related to his personal characteristics, task performance and performance background. 
Table 1. International federation of accountants on the definition of accounting vocational education competency characteristics

\begin{tabular}{|l|l|}
\hline \multicolumn{1}{|c|}{ Characteristic categories } & \multicolumn{1}{|c|}{ Competency characteristics } \\
\hline Professional knowledge & $\begin{array}{l}\text { Knowledge of financial accounting, enterprise management and computer } \\
\text { application }\end{array}$ \\
\hline Professional skills & $\begin{array}{l}\text { Analytical, collaborative and communicative skills, organizational and } \\
\text { managerial skills }\end{array}$ \\
\hline Professional attitude & Professional ethics and law compliance \\
\hline
\end{tabular}

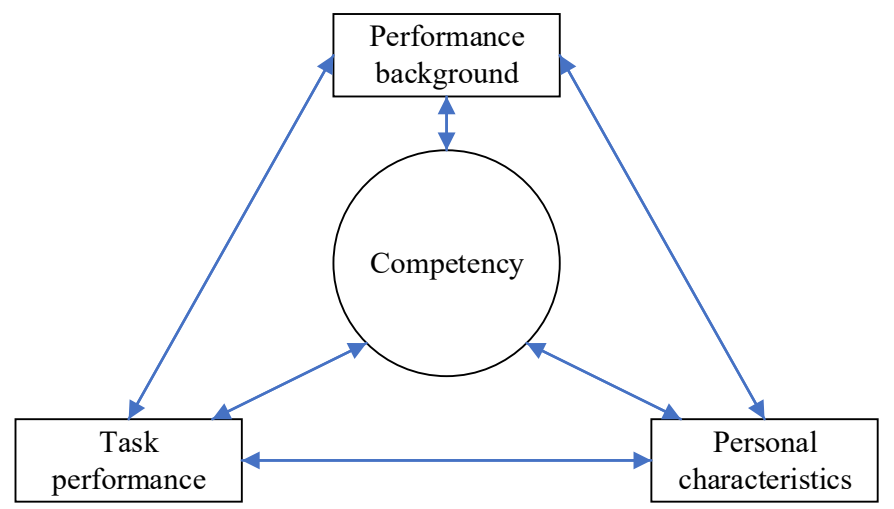

Fig. 2. The relationship between competence and personal characteristics and task performance

\section{Competency Factor Analysis and Model Construction of Accounting Vocational Education}

\subsection{Analysis for competency factors of accounting vocational education}

In the competency criteria, the specific requirements of competency are defined, including accounting vocational education examination system, continuing education system and evaluation system. It's the core function of accounting vocational education to train the competent accounting practitioners. According to the competency requirements of accountants, the examination system, admission system, and continuing education system have been designed. Accounting education competency is related to the level of education, which is reflected in the training and learning of accounting skills, while learning skills are related to the value contribution of accounting professions; the competence of accountants involves the personal attitudes and behaviours of individuals ready for the accounting profession. Figure 3 is the standard framework of accounting vocational education competency. For those who are specialized in accounting, the focus is on competency factors and performance standards, and personal characteristics also determine professional competence. Figure 4 shows the competency factors of accounting vocational education, including management and leadership ability, aggressiveness, social responsibility, market development abil- 
ity, risk control ability, project management ability, communication ability and audit related business knowledge in this study.

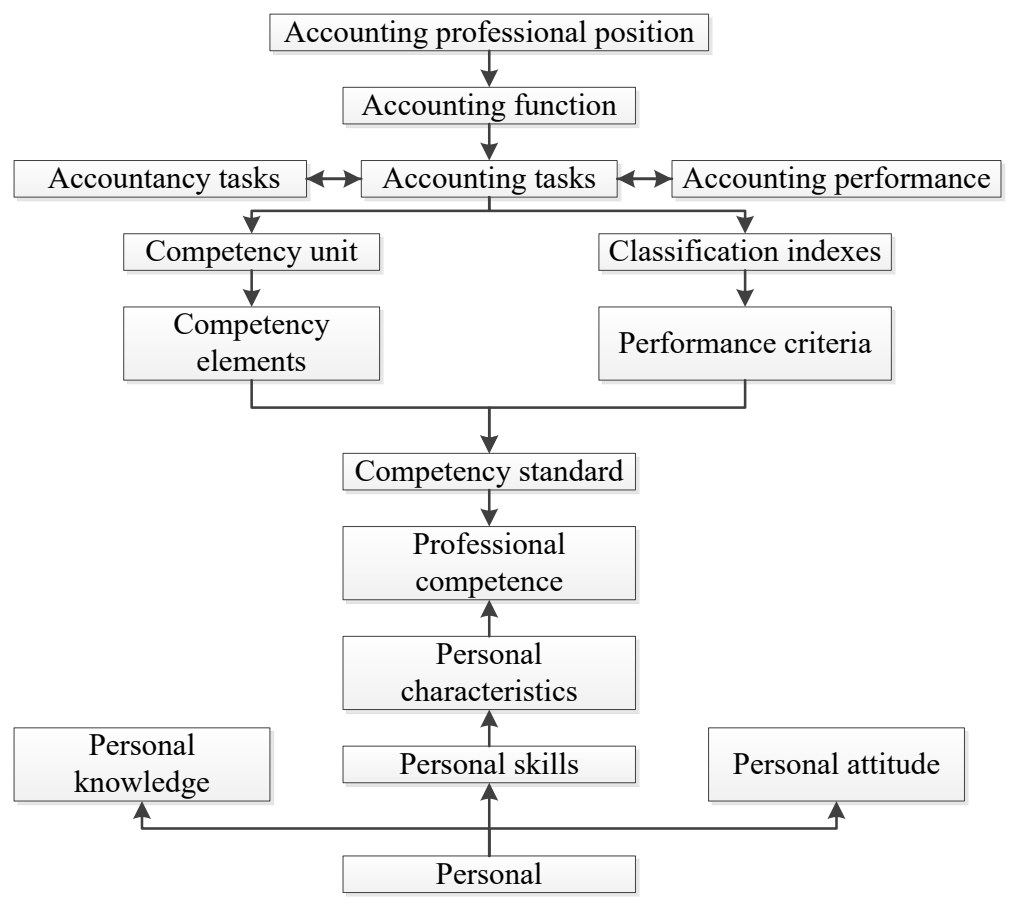

Fig. 3. Accounting vocational education competency standard framework

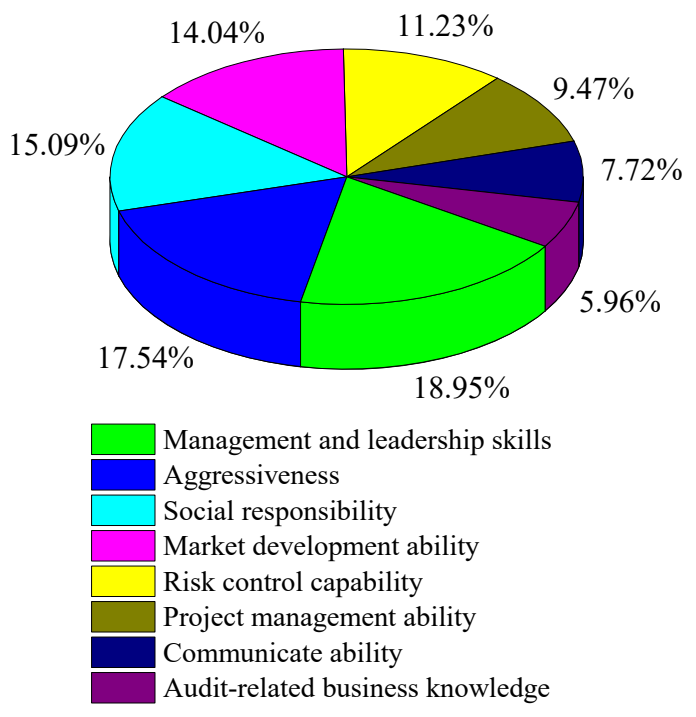

Fig. 4. Accounting vocational education competency elements 


\subsection{Competency model construction of accounting vocational education}

Figure 5 shows the competency model of accounting vocational education consisting of accounting professional knowledge, accounting professional skills, personal traits and accounting professional ethics. The main accounting professional knowledge includes financial accounting knowledge, accounting management knowledge, and tax declaration and planning; personal traits focus on analysis and judgment ability and detail processing ability. In this paper, 90 accounting vocational educators were investigated, including 50 leading figures in accounting vocational education, named excellent group; 40 general accounting vocational educators, named ordinary group. The behavioural characteristics of 90 respondents were coded. Most of the excellent group have outstanding performance and excellent ability in the industry, with an average age of about 46.7 years; the respondents in the ordinary group are mostly $\mathrm{PhD}$ graduates, with the average age of teaching of 4.4 years.

Figure 6 shows the differences in the evaluation scores of the competency factor between the excellent group and the ordinary group. It can be clearly seen that there are significant differences between the two groups in the management and leadership, aggressiveness, social responsibility, risk control ability, communication ability and audit related business knowledge; on the whole, the excellent group is higher than the ordinary group in each competency factor. By the t-test, it's found that the total score of the excellent group was much larger than that of the ordinary group, and there was a significant difference between the two groups. This paper builds a competency model by means of two groups of accounting vocational educators.

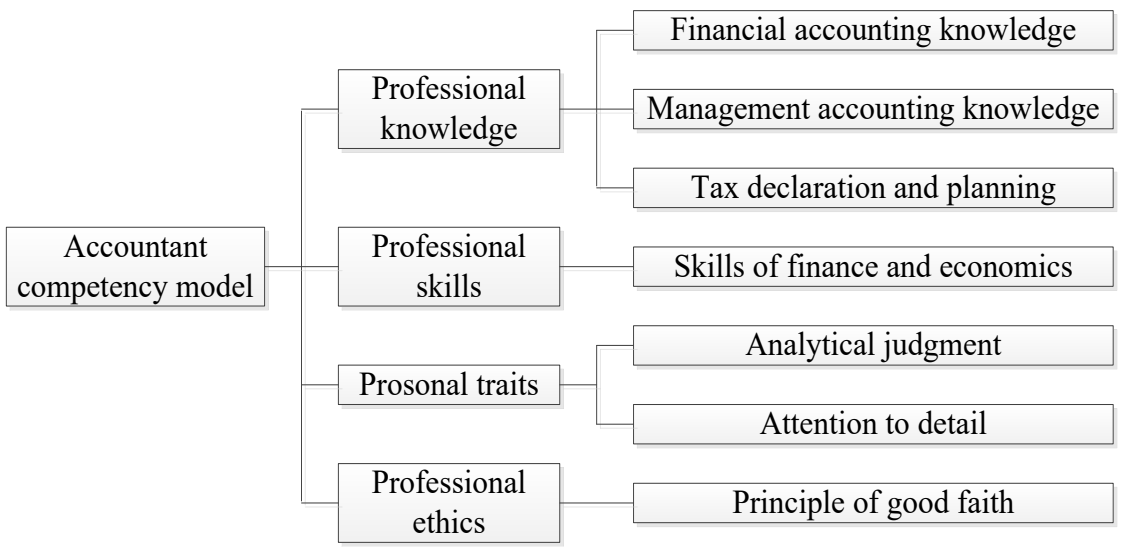

Fig. 5. Competency model of accounting vocational education 


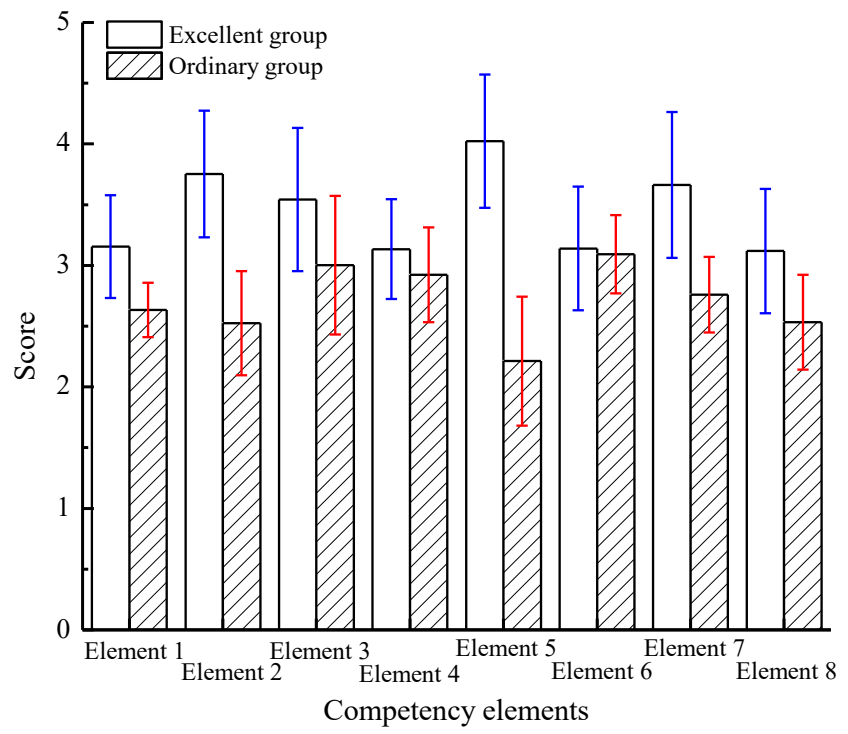

Fig. 6. Comparison of competency factor evaluation scores between the excellent group and the ordinary group

\section{Model Verification of the Accounting Vocational Education Competency}

\subsection{Application of competency model of accounting vocational education}

Through the form of interviews, the accounting vocational education competency model was established. The questionnaire survey (5-point system) was used to evaluate the competency factors of this model. 180 questionnaires were distributed and 169 valid questionnaires were returned. Most of the respondents have rich experience in accounting education or practice. Accounting competency factors were derived from competency framework analysis, industry representative key event analysis and expert discussion, so it has been widely recognized by accounting practitioners.

Figure 7 shows the average score of competency factors in accounting professional education. It can be seen that management and leadership ability has the highest score, followed by communication ability and aggressiveness, and social responsibility has the lowest score. There is a correlation between various factors of competency, and this correlation divides the eight factors into different categories, each of which has a corresponding factor. In order to understand whether there is stability and consistency between the relevant variables of the questionnaire results, we used Cronbach's $\alpha$ reliability test method. The Cronbach' $\alpha$ coefficient reflects the degree of consistency within the sample, between 0.6-0.7 it's is acceptable, between 0.7-0.8 it has high reliability, and with the value greater than 0.8 , it indicates a very good reliability. Figure 8 shows the Cronbach' $\alpha$ coefficient of the competency factors in ac- 
counting vocational education. The Cronbach' $\alpha$ coefficient and the average score do not show the same change rule. The Cronbach's $\alpha$ reliability of management and leadership ability, market development ability and communication ability were greater than 0.8 , with very good reliability; overall, Cronbach's alpha reliability values are all are acceptable when above 0.6 .

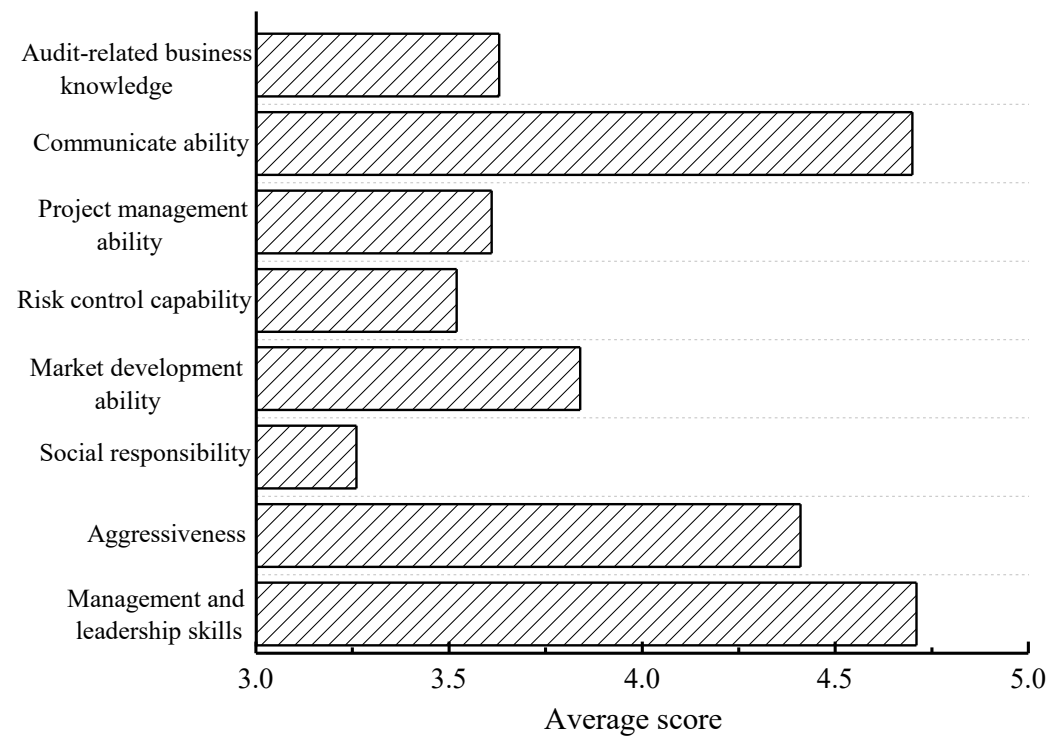

Fig. 7. The average score of accounting vocational education competency education

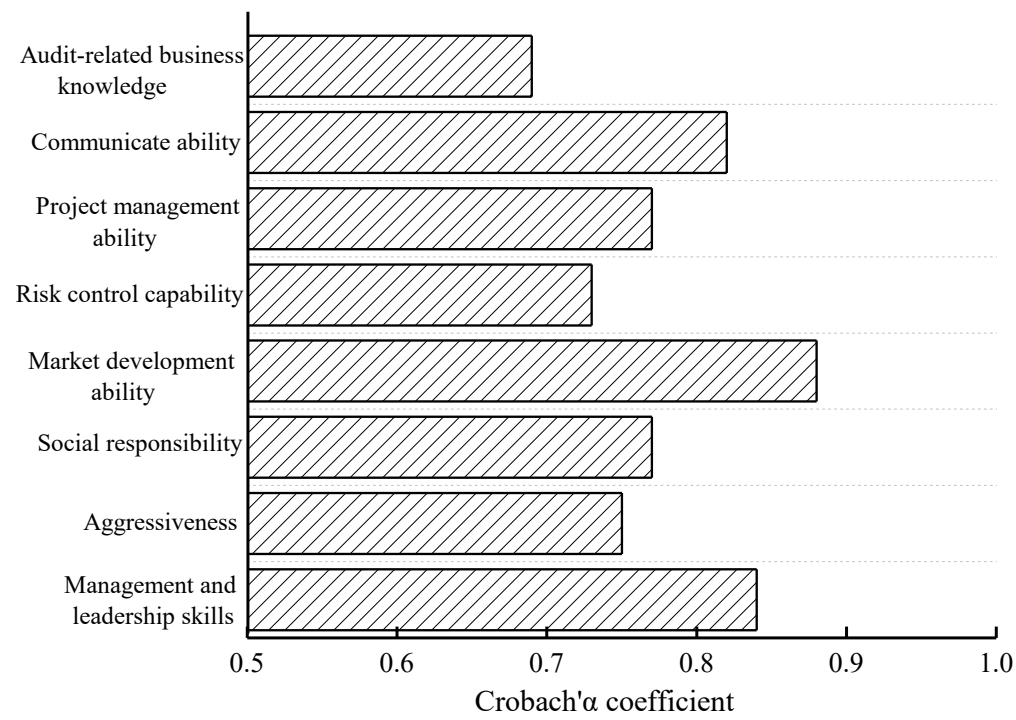

Fig. 8. The Cronbach' $\alpha$ coefficient of accounting vocational education competency factors 


\subsection{Countermeasures and suggestions of accounting vocational education competency}

From the average scores of the competency factors and Cronbach's $\alpha$ reliability test, it's found that the primary competence factor of accounting vocational education is management and leadership. Figure 9 shows the competency model of excellent accounting vocational education. Excellent accounting vocational educators should enjoy the outstanding management and leadership skills, accounting ability and accounting professional skills. Figure 10 shows the decomposition diagram of the influencing factors of accountants' competence. From the perspective of professional education, the accounting practitioners trained in the educational process should perform the accounting function in their work. The most fundamental point of education is to cultivate the talents needed by the enterprise with leadership, professional skills, and theoretical knowledge etc. Post competency is affected by internal influencing factors and external needs, where internal factors mainly refer to corporate management, and external factors are mainly tax administrators; if one is recognized by both, it means that their competence has been greatly improved.

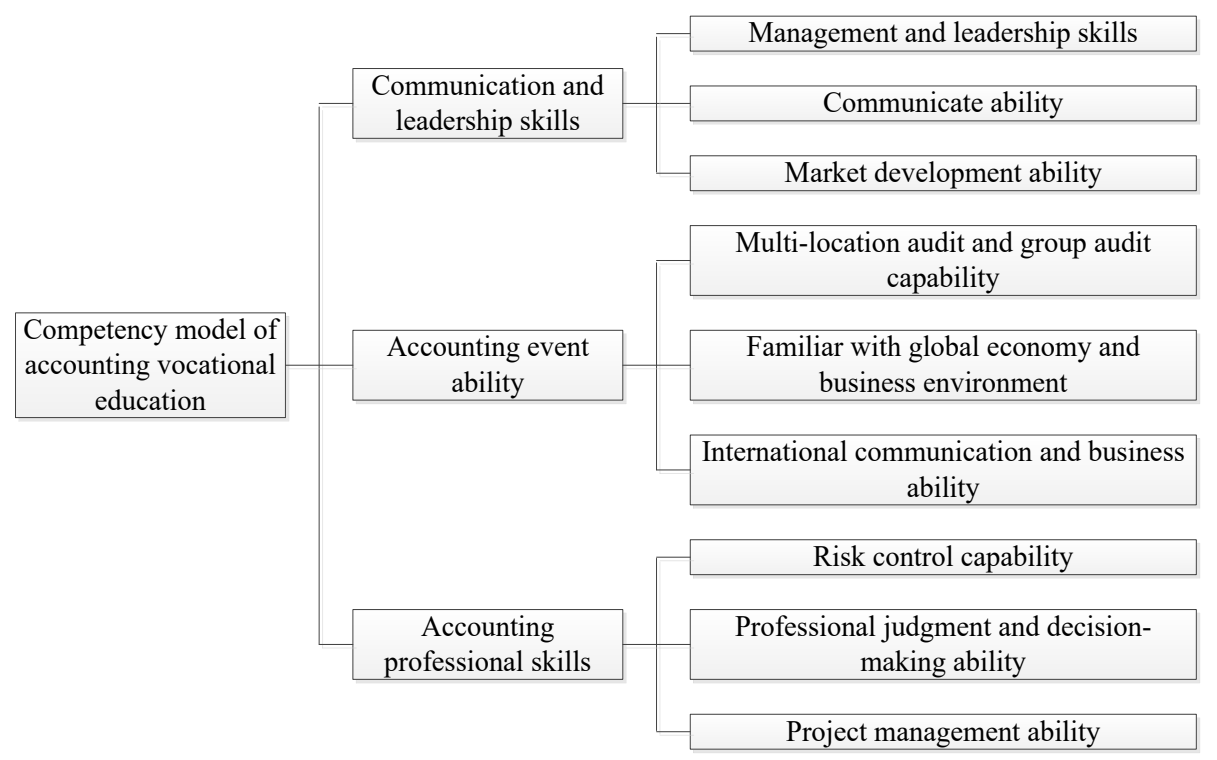

Fig. 9. Competency model of excellent accounting vocational education

In order to ensure the long-term development of the accounting vocational education competency, a corresponding incentive system should be established. In the aspect of accounting education, the curriculums for cultivating the personality characteristics of accounting majors should be added to stimulate students' potential; in addition, the teaching methods should strive for innovation, because the traditional teaching methods are difficult to achieve intensive training of professional literacy. Therefore, in the process of accounting education, students should be encouraged by the 
evaluation and behaviour of teachers, so that students can achieve their goals according to their own learning methods, and then influence others, thereby forming a benign incentive system.

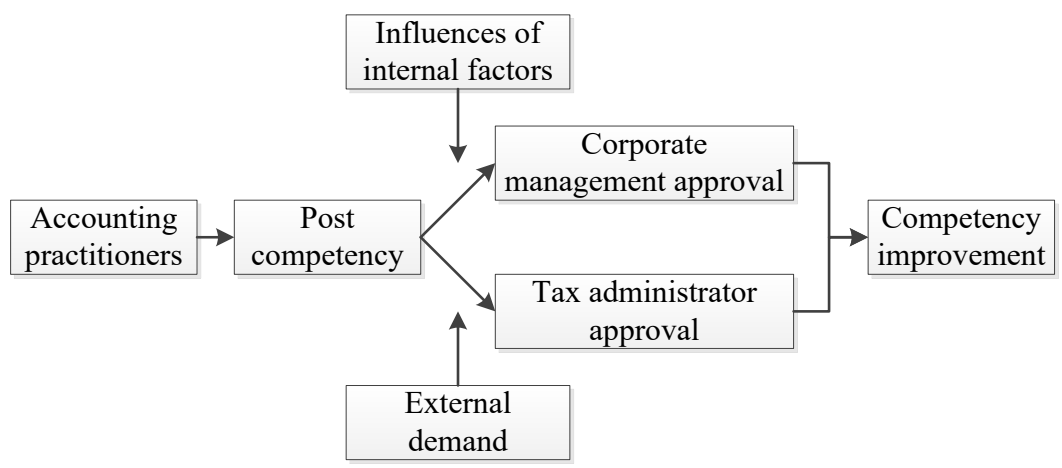

Fig. 10.Decomposition diagram of influencing factors of accounting personnel competency

\section{Conclusion}

In light of the construction and application of competence model, this paper explores the competency of accounting practitioners under the accounting vocational education, and also gives countermeasures and suggestions for the improvement of the competency. The specific conclusions are as follows:

- There are 8 competency factors of accounting vocational education: management and leadership ability, aggressiveness, social responsibility, market development ability, risk control ability, project management ability, communication ability and audit related business knowledge;

- In the evaluation of competency factors, there are significant differences between the two groups in the management and leadership, aggressiveness, social responsibility, risk control ability, communication ability and audit related business knowledge; on the whole, the excellent group is higher than the ordinary group in terms of each competency factor;

- The applied research of the vocational education competency model found that the highest score is management and leadership ability, followed by communication ability and aggressive, the lowest score is social responsibility. There is a correlation between various factors of competency. Through the consistency test of test samples, it's found that Cronbach's $\alpha$ reliability of management and leadership, market development ability and communication ability were greater than 0.8 , indicating very good reliability; overall, Cronbach's $\alpha$ Reliability values greater than 0.6 are acceptable;

- In the accounting education, the curriculums for cultivating the personality characteristics of accounting majors should be added to stimulate students' potential. It is 
the ultimate goal of accounting vocational education to enhance the competence of accounting vocational education through incentive measures.

\section{Acknowledgement}

This study was supported by Hunan Education Reform Project: Professional Ability-oriented Teaching Research and Reform of Audit Course (Hunan Education Tong [2018] 436).

\section{$7 \quad$ References}

[1] Klotz, V., Billett, S., Winther, E. (2014). Promoting workforce excellence: formation and relevance of vocational identity for vocational educational training. Empirical Research in Vocational Education and Training, 6(1): 6-12. https://doi.org/10.1186/s40461-014-0006-0

[2] Helm, C. (2015). Determinants of competence development in accounting in upper secondary education. Empirical Research in Vocational Education and Training, 7(10). https://doi.org/10.1186/s40461-015-0022-8

[3] Bots, J.M., Groenland, E., Swagerman, D.M. (2009). An empirical test of birkett's competency model for management accountants: survey evidence from dutch practitioners. Journal of Accounting Education, 27(1): 1-13. https://doi.org/10.1016/j.jaccedu.2009.06.001

[4] Baumeler, C. (2017). Competence-based vocational education and training and its cultural context sensitivity. European Education, 51(1): 1-15. https://doi.org/10.1080/10564934.20 $\underline{17.1344503}$

[5] Bohne, C., Eicker, F., Haseloff, G. (2017). Competence-based vocational education and training (vet). European Journal of Training and Development, 41(1): 28-38. https://doi. org/10.1108/EJTD-07-2016-0052

[6] Kuijpers, M., Meijers, F., Gundy, C. (2011). The relationship between learning environment and career competencies of students in vocational education. Journal of Vocational Behavior, 78(1): 21-30. https://doi.org/10.1016/j.jvb.2010.05.005

[7] Bruijn, E.D., Leeman, Y. (2011). Authentic and self-directed learning in vocational education: challenges to vocational educators. Teaching \& Teacher Education, 27(4): 694-702. https://doi.org/10.1016/j.tate.2010.11.007

[8] Koopman, M., Teune, P., Beijaard, D. (2012). How to investigate the information processing strategies of students in competence-based pre-vocational secondary education: selection of the right instrument. Quality \& Quantity, 46(6): 1931-1946. https://doi.org/10.10 07/s11135-012-9772-6

[9] Braun, E.M.P., Sheikh, H., Hannover, B. (2011). Self-rated competences and future vocational success: a longitudinal study. Assessment \& Evaluation in Higher Education, 36(4): 417-427. https://doi.org/10.1080/02602938.2010.534762

[10] Grollmann, P., Grollmann, P. (2008). Professional competence as a benchmark for a European space of vocational education and training. Journal of European Industrial Training, 32(2/3): 138-156. https://doi.org/10.1108/03090590810861686

[11] Hooge, E. (2015). Connecting with the world of work: horizontal accountability processes in institutions providing vocational education and training (vet). European Journal of Education, 50(4): 478-496. https://doi.org/10.1111/ejed.12155 
[12] Hager, P. (2004). The competence affair, or why vocational education and training urgently needs a new understanding of learning. Journal of Vocational Education \& Training, 56(3): 409-433. https://doi.org/10.1080/13636820400200262

[13] Reegad, K. (2015). Diversity of occupational orientations in sales vocational education and training. Journal of Education and Work, 29(6): 688-706. https://doi.org/10.1080/136390 $\underline{80.2015 .1024642}$

[14] Kutluk, F.A., Gulmez, M. (2012). A research about distance education students' satisfaction with education quality at an accounting program. Procedia - Social and Behavioral Sciences, 46: 2733-2737. https://doi.org/10.1016/j.sbspro.2012.05.556

\section{Author}

Jinglei Zhong, female. She graduated from Curtin University of Science and Technology in Australia in 2009, and currently work in Business School of Hunan International Economics University. She is a professional accountancy teacher, and mainly teach core courses such as accounting computerization, auditing and financial management. She published more than ten academic papers, presided over one provincial education reform project, and participated in one provincial social science fund project. In April 2017, she instructed students to participate in the finals of the National Business Elite Challenge Competition "Opening Course Cup" Accounting and Business Management Competition, and won the first prize of the team. In May 2018, she instructed students to participate in the finals of the National Business Elite Challenge Competition "Opening Course Cup" Accounting and Business Management Competition, and won the second prize of the team. In October 2018, she won the second prize of Hunan University Information Competition.

Article submitted 2019-07-21. Resubmitted 2019-09-13. Final acceptance 2019-09-23. Final version published as submitted by the authors. 